\title{
Terrorism in Nigeria: The Case of the Boko Haram
}

\author{
Bosede Awodola, PhD \\ Institute for Peace and Conflict Resolution, Abuja \\ boseaw02003@yahoo.com \\ Caleb Ayuba \\ Institute for Peace and Conflict Resolution, Abuja \\ ayubacaleb@rocketmail.com
}

Doi:10.5901/mjss.2015.v6n4s2p247

\begin{abstract}
This work examines the complex phenomenon of global terrorism in a fast evolving International Order (the New World Order) that is driven by the wheel of globalization as a historical process. The discourse is domesticated within the Nigeria geographical space with the onslaught of the Boko Haram attack on the Nigerian state; its premier institutional bulwark represented by the military and its vulnerable populations as case study. The article presents Nigeria as a deeply divided society that is exploited by the terrorist to their advantage. The work contained herein is anchored on the failed state and the relative deprivation theoretical model to sustain its thrust and give meaning to the arguments articulated. The methodology depended-on for data leans heavily on the analysis of secondary sources within the traditional liberal and social science orientations. Finally, the article presents a set of recommendations that could contribute in the reversal of the grounds covered by the Boko Haram since the highly ghoulish movement launched its macabre push against the symbol of Nigeria's legitimacy as a sovereign state amongst other international system of states.
\end{abstract}

Keywords: Global Terrorism, War, Jihad, Boko Haram, Small Arms:

\section{Introduction}

Terrorism has become one of the most important concepts that have continued to shape intellectual discourses in post Cold War international system. This phenomenon has become a potent instrument in the hands of renegade elements 'privileged' to bear arms within the boundaries of states (Ayuba and Okafor, 2014). In this respect, this paper addresses the challenge posed by the Boko Haram terrorist movement in Nigeria. A phenomenon that is fast spreading, beyond the West Coast to the Central African regional bloc with its evil and catastrophic effects devastating lands and peoples. The paper hinges its argument on the assumption that even though the insurrectionists have consistently claimed origin in the Islamic faith, evidence have sustainably proven otherwise.

The focus of this study therefore is to give a vivid and coherent perspective with regards to the activities of the Boko Haram movement with a view to tracing the source of and the motivation for the insurgency. Also, the paper establishes the implication of the activities of the Boko Haram on livelihood and human rights questions, while also taking a critical examination of the nexus between the insurgency and the free flow of illicit Small Arms and Light Weapons (SALW) marketed within Africa. To entwine its perspective, the paper sorely leaned on the review of existing literatures covering the global terrorist phenomenon since it became a choice strategy in the neutralization of perceived enemy forces. Such literature includes Journals, Books, Reports as well as internet materials. The paper is structured along six parts with the theoretical perspective following the introduction, while the third part deals with the global perspective of terrorism and overview of Boko Haram sect in the fourth part. The fifth part focuses on the implication on livelihood and human rights questions. Recommendation and conclusion formed the final part.

\section{Theoretical Underpinning}

To explain the occurrences of violent conflicts unfolding within global space since the collapse of the 'Iron curtain', scholarly endeavors to explain these conflicts have led to the evolution of the state failure theory which seeks to explain the scale of this violence. This paradigm is championed by scholars like Rotberg (2002) and Zartman (1995). These 
scholars and many more that subscribe to this school of thought have maintained that to understand any intrastate conflict, the starting point of scrutiny should be by the thorough examination of the strength/weakness and the stability/disorder inherent within states at any particular time. Thus, they begin their investigation with the assumption that weak states are responsible for the outbreak of disorder within the boundaries of states. They opine too that problems associated with fragile political systems and economies could deteriorate into humanitarian emergencies consequent on the response of a depressed citizenry.

Thus, the leading American foreign policy specialist, Henry Kissinger (2001), has described a "state" as the "expression of some concepts of justice that legitimizes its internal arrangement and of a projection of power that determines its ability to fulfill its minimum functions-that is, to protect its populations from foreign dangers and domestic upheavals. Other conditions include the ability to provide efficient service to the people constituting the confederation. Amongst these services include physical security, basic health care, education, transportation and communication infrastructure; monetary and banking systems and a system or mechanism that enhances the peaceful resolution of identified conflict questions between 'national entities' within a country. A state that lacks the capability to institutionalize law and order could not be grouped in the category of strong states (Udoambana, 2006: 6). In this vein, Maiangwa et al (2013) have summed the matter thus, 'Once the state is unable to perform these primary responsibilities, it loses its legitimacy in the eyes of the citizens, many of whom will then naturally transfer their allegiances to more responsive authority groups or figures-religious, clan, or group leaders-while others will go even further by becoming terrorists'

It is in the light of this theoretical perspective that we can understand the insurgency of the Boko Haram. Since the article wishes to situate its over-all discourse on the economic and the social malady confronting the average northern Nigerian, which is seen as an important reason for the violence as the fulcrum of its argument, the weak state theoretical model that seeks to explain the inability of the state to curb the menace of poverty and economic depression and the resultant onslaught will be apt. This is imperative with regard to the Failed States Index, Nigeria has on a consistent basis been featured as one on the brink of total collapse; 'currently, it ranks fourteenth on the list-which makes it close to other countries that have experienced total collapse in recent times' (Foreign Policy, 2011).

Another equally relevant theory that will complement the failed state thesis is the relative deprivation theory. This theory subsists in the assumption that when states fail and individuals and human groups within the state feel aggrieved because of the deprivation that they are subjected to because the state is unable to cater for their basic needs they rebel (Gurr, 1970). These needs include the provision of health services, security, food, jobs, and infrastructural services and so on. According to Maiangwa et al (2013), it is this deprivations and its concomitant aspect of the poverty it breeds that has birth the millions of youths that fall prey to the extremist ideologies of the Boko Haram. These youths have become so frustrated that they have made every symbol of the state and its authority their target. In the desire to vent their angst, these youths have killed soldiers, members of the police force, religious centers and other property destroyed as well as abduction of innocent people.

\section{Global Terrorism in Perspective}

The Postmodern phase of human evolutionary advance which coincides at the cross-roads with the landmark trend of the end of the Cold War has resulted in the growth of shades of perspectives intended to shape both the theoretical and pragmatic global future. It was while responding to Francis Fukuyama's (1992) triumphalists' assumptions of the 'End of History' that Samuel Huntington (1996) conceived an equally potent model to give meaning to contemporary global conflict relations. In his 'Clash of Civilizations and the Remaking of World order' theses, Huntington has firmly held on to the thinking, which is at variance with Fukuyama's position that man (the specie) will continue to threaten man; according to Huntington this may not be at the trans-national levels. Conflict in this phase will be at the ethno-religious and civilizational realm and these will unfold within the territorial margins of nation-states. In contemporary human and group socio-economic and political relations, this model has proven relevant in illuminating the unfolding incidences of violent conflicts including their asymmetrical variant.

The article posit from the onset that the acts of terrorist within the Nigerian geographical space are actually a declaration of war against the state. This conclusion is instructive because of the observable complex dynamics defining the unfolding phenomenon in all its gruesomeness. Contrary to the known tactic of terrorist globally which prefers the "hit and run' approach, the Boko Haram variant is markedly distinct in the sense that its 'victories over the security institutions' have propelled them into crafting a new thinking to the strategy of terrorist movements which subsists on the assumption that renegade movements can literally invade and acquire territories. In this instance, the Boko Haram has conquered a large section of the north eastern Nigeria; a situation that informs Tatalo Alamu's (2014) conclusion that with this brazen effrontery, Nigeria has become effectively partitioned. 
By war, we will be inferring 'organized violence carried on by political units against each other' (Bull. 1977: 184). However, violence could not be ascribed the tag 'war' until it fulfills the basic condition of its being 'carried out in the name of a political unit (Boko Haram) against another political unit (the state). For the purpose of dispelling any ambiguity between the legal definitions of war and peace, Hugo Grotius has constructed the doctrine of inter bellum et pacem nihil est medium (Bull, 1977). Under this principle, Grotius attempts an understanding of the meaning of war by asking the question 'at what point does the rebel band (the Boko Haram in this case) takes on the character of a political unit. We will provide the answer immediately by saying, the moment that rebel band bears arms, conquers territories and undermine the constitutionally acclaimed authority presiding over the conquered territory, the same rebel band has assumed the title of a 'political unit'. Secondly, the principle operates under the normative assumption that if war is to be war, then the 'persons conducting this hostilities must be activated (motivated) by the notion that they are engaged in an activity called war' (Bull, 1977: 186). The Boko Haram has severally described their hostilities against the Nigerian state and its fatigued people as a Holy war against infidels (Salkida, 2009). In the same breath, Laderach (1997: 5) has joined in the discourse by stating that 'war is reserved to describe a conflict in which at least one thousand deaths have resulted in a given year. The Boko Haram onslaught has met this bleak statistical requirement.

This is the background that will give us the meaning of the phenomenon of the Boko Haram threatening the national socioeconomic and political narrative. In this respect, it is necessary to maintain at the outset that what the world is transiting through is the challenge to global security order. Thus, the classical model of the social contract as originally constructed by 'the humanists Thomas Hobbes (1946) and advanced by other like-minded classical thinkers like Locke and Rousseau (1927) is undergoing the process of radical re-definition' (Ayuba and Okafor, 2014). Individuals and human communities residents within national borders, previously suppressed and subjected to the authority of leviathan (the state) as the check to perceived human 'excesses' is currently being challenged and its power to tame these 'excesses' increasingly questioned by groups that had earlier completely submitted their will to resist the state because of its monopoly of the instruments of coercion - arms and weapons sorely borne by military and security institutions. This rebellion against state authority is emanating from the open access that anarchist, religious extremist and irredentist; ethnic nationalists and criminal entities have to the floodgates of arms supply chains. The illicit weapons available to these elements since the end of the Cold War and the phenomenally catastrophic collapse of previously established centers of organized power like Iraq under Saddam Hussein, Libya under the firm grip of Muammar Qaddafi, Afghanistan and recently Syria under the relentless Assad have continued to facilitate the heinous occurrence of insecurity within fragile state formations (Ayuba and Okafor, 2014).

Until now, a critical examination of Nigeria's security portfolio easily reveals that previous national security concerns were focused primarily against threats posed the national interest by external militaries in the pursuit of their own strategic socio-economic and political interests on Nigeria's air, maritime and land territorial spaces. Due to this limited orientation and understanding of the core elements constituting the concept of national security, the security establishment, charged with the responsibility of shielding the state from external threats have consequently decided it was not within its constitutional domain to manage internal security, until the dynamism shaping the movement of history permanently altered that limited mindset with the emergence into the political scene of the Boko Haram elements and their capacity for unleashing infamy on individuals and groups (Imoibighe, 1990: 224).

With specific reference to discourses on terrorist tendencies and religious fundamentalism, Huntington (1994) has maintained that because of the sweeping religious revival or what he describes as la revanche de Dieu, human spiritual being is being activated in a global religious revival and man's consciousness with regards his eternity in constant reckoning. He is constantly engaged in an exercise of self inquiry. He asks the fundamental question bordering on the dual aspects of his temporal humanity and its accompanying opposite-his timeless eternity. In the process of this introspection that informs deep spiritual contemplation, such questions arise; who am I, what am I doing here (on earth) and where am I going afterwards? To each of these questions, he gains deeper spiritual insight that reveals and provides him with an answer that confirms that he has a destination in the hereafter, thus the need to engage in pious conduct that will reconcile him to his maker for the ultimate Day of Judgment (Huntington, 1994). On the same subject, Le Kuan Yew, commenting on the issue has referenced the East Asia locale when he opines that 'there is a quest for some higher explanations about man's purpose and about why we are here (Huntington, 1994: 97).

Thus, the average religious bigot engages in fundamentalist acts with the hope that he will attain eternal life by these pious acts against those he perceives as 'infidels'. . Accordingly, a Hezbollah functionary, Sheik Naim Qassem, 'the Hezbollah number two'; has developed in many of his treatises and interviews what is tortuously perceived as a well reasoned justification for suicide bombings. He posits that in the real sense, these attacks have nothing to do with suicide. He captures his defence in the following quixotic epistle:

Jihad is a fundamental basis for us. We do not use it as a means of imposing our views on others, but consider 
ourselves in a state of Jihad to defend our rights. When a Muslim dies in a defensive Jihad, he fulfils........ his religious duty by waging a holy war as well as gratifying God by making the ultimate sacrifice.......since we believe that our moment of death is recorded and determined by God, it follows that whether one hides in a shelter, is crossing the road or is fighting the enemy, he will die when his time arrives (Reuter, 2002: 64).

What the functionary is making effort at establishing is that every unfolding phenomenon affecting a person, whether they are positive or negative have been pre-ordained, thus the justification of the theological construct of predestination. In other words, no man can escape what is due to him even if for one minute. This spiritual thought gives the adherent reason(s) to embrace doctrinal instructions that direct him in the path of suicide. In this vein, the demagogue sheik continues ' Having established this, it follows that when a fighter goes to fight a jihad we do not consider him to be taking any more risks than the next man nor do we think he is bringing his moment of death closer'. So, all he has done is to pick the way in which he will die. 'If you understand Islam, you will undoubtedly be able to comprehend that this person is not being killed prior to his time. From here we regard martyrdom as a Muslim's choice of the manner in which he seeks to die' (Reuter, 2002).

However, the above narrative, including Huntington's views which according to Mamdami (2002) has demonized Islam, have been criticized by currently emerging thinking and the vast literatures containing these thoughts that are beginning to form new paradigms covering the terrorist question. This modified line of argument; that the terrorist link is not with all of Islam, but with a very literal interpretation of it, one found in Wahhabi Islam is becoming the acceptable norm in religious interpretations (Mamdami, 2002). It is very clear that no religion, endorsees lethality or a killing culture in human society. Allah in the Qur'an 5: 32, has thus prescribed-as law-for the children of Israel that whoever kills a person otherwise than - in retaliation - for another person, or for causing corruption in the land, Shall be as if he had killed the people in a body" (Paige, 2009). This confirms that unlike the highly deceptive narrative of the above Hezbollah operative, Islam as variously contained in the Qur'an does not endorse extremism in any form.

To discountenance the existence of any nexus between Islam and any terrorist activities, especially with regards the activities of the Boko Haram, General Muhammadu Buhari, a former military Head of State of Nigeria has publicly ascribe the tag 'evil terrorist organization' to the Boko Haram. Recently stupefied at the staggeringly evil strategy of the Boko Haram, our referenced Muhammadu Buhari had declared, 'The perpetrators may look like human beings, they may have limbs, and faces like the rest of us but they are not like us. In killing innocent people, they have become inhuman'. According to the Maverick Military General these terrorists subsist outside the scope of rational humanity. 'Their mother is carnage and their father is cruelty. They have declared war on Nigeria and its people......yet they shall fail and the good people of Nigeria shall triumph' (Ocholi, 2014: 12).

More so, throughout history, people claiming to be pursuing the propagation of certain religious tenets have been seen to be perpetrating terrorists' acts. For instance, in the $1^{\text {st }}$ century $A D$, the Maccabees under Judah Maccabees, the Essence and the Zealots, all Jewish Sects carried out acts of terrorism against the Roman Empire that had occupied Jerusalem after its conquest by General Titus in 70 AD (Ariela Pelaia, 2012). Still within Jewry, the Zealots-Sicarri, a group of Jewish terrorists took the oath to be seditious and riotous against the authority that presided over the Jews of that day. Hence, they stirred revolts against Roman rule in Judea. In the process, they frequently murdered their chosen victims with the edge of the sword and daggers in broad daylight in the heart of Jerusalem during the roman occupation. 'Other early terrorist movements include the Hindu Thugs and the Muslim Assassins. Modern terrorism, however, is generally considered to have originated with the French Revolution' in the 18th Century (Cronnin, 2002: 35). In recent times, the Irish who professed either Catholicism or Protestantism were all pronounced culpable in perpetrating extremist activities (Bernstein, 2012: 105). This is apart from the Moist in India and many other such movements whose activities can be appreciated only when connected to the political narrative directing them.

\section{Boko Haram Sect in Perspective}

The history of the Boko Haram has roots in other equally catastrophic social and politically motivated violent conflicts like the Maitatsine induced security challenge of the early 1980s. Thus, it will be correct to sum that the ghoulish narrative of ethno religious conflicts in Nigeria will make no sense except it is contextualized within the framework of its infamous origins in the Muhammadu Marwa (Maitasine) organized uprisings of earlier decades. Marwa had successfully mobilized elements within the northern Nigeria locale, and with a combination of the power of oratory and a previously unimaginable energy plunged these elements against the state and its authority. Analyst have contended that Marwa's demagoguery was previously unimaginable in its malevolent potency; his oratory, which was mixed in an evil alchemy with the social malaise amongst a people undergoing socioeconomic depression produced a ferment that was never seen in the history of Nigeria's nationhood. Thus, under the banner of religious Jihad, Marwa mobilized the dregs of human society who after 
massive indoctrination and the invocation of the hate mentality unleashed terror on the citizenry in the northern cities of Kano, Kaduna, Maiduguri and so. The chronicles have it that;

The biggest mayhem as a result of social malaise in the north arose from the Maitatsine insurgency which found breeding ground in an ambience where religious ethno-identification is the principal political ideology. Muhammadu Marwa who started his insurgency was originally from northern Cameroun, he was deported in 1945 by the then colonial government, but returned to Kano in the 1970's, by the time his seed of discord based on a promise to reduce social disparity between the rich and the poor usingSharia law gained ground, his movement's confrontation with the government had giving rise to many deaths; 5000 in Kano in the 1980's, 3000 in Maiduguri and Kaduna, and later over 1000 deaths in Yola under the resurgent leadership of Mallam Makaniki (Editorial, 2014).

In the process, thousands of people were killed as observed above and invaluable amounts of properties destroyed. With regards this grotesque national narrative, It has been maintained that since the 'success' of the Maitasine onslaught against the legitimacy of Nigeria's state power, this model has increasingly served as motivation for other likeminded anarchic elements within civil society. In relation to the Boko Haram, the movement has also, in a consistent manner mobilized their followership; using the platform of religion, ethnicity and the ever increasing social discontent as reason to undermine national order and stability. In the process again, thousands have been killed since the Boko Haram insurgency began some seven years ago, specifically in 2009.

Recently, it has been established that because of the incendiary tactic of the Boko Haram, over 12, 000 people, including women and children have been displaced to the neighboring Niger republic, particularly to Bosso in the state of Diffa. The seriousness of the matter is best understood when the fact that the insurgent movement has now captured and controls over $20,000 \mathrm{sq}$ of land and terrorizes a very large chunk of the north east of the country. These circumstances have been confirmed by Issa Amadu of the International Rescue Committee -- IRC-an agency of the French government. (Idris, 2014: 6; Yusha'u, 2014: 3). In addition, the near apocalyptic ferocity of the menace must be responsible for pushing the people of Adamawa into the mountains and eventually into Cameroun and Niger. In a radio life programme in the Federal Capital Territory Vision FM radio, Ibrahim Moddibo of the Adamawa Peoples Association had given the scary statistic that over 150, 000 of Adamawa people have fled to these countries and are now refugees.

At inception, the movement's motivation was easily traced to religious ideology that favored fundamentalism. But this has long changed to accommodate the now famous construct of the 'terror economy' as conceived by Napoleoni. The terror economy model for explaining the terrorist actions premises it assumption on the belief that the act is nourished by economic thoughts rather than any other consideration. Thus, the current modus operandi of the Boko Haram includes kidnappings for ransom and human trafficking, a phenomenon that is increasingly becoming a thriving criminal business with annual net returns in billions of US dollars across the world. The Boko Haram has also perfected its armed robbery operations. Up till now, there is no known record of any failed Boko Haram bank robbery operation. Thus, in the process, they cart away huge sums of money that increases their financial fortunes. With regards the Alqaeda in the Maghreb (AQIM), operating in the Central Sahara environment, it has been established that, as at the year 2011, it was estimated that the AQIM's financial holdings ran into over one hundred million USD. These are accruals from proceeds from drug trafficking, the kidnapping business and other such equally heinous operations. Lohmann (2011) has opined that these accruals and the increasing volume of arms cache at the disposal of the AQIM in the following manner; "The AQIM is still at the money collecting phase. It could soon begin using these revenues for other terrorist attacks.

Still on the doctrine of the terror economy sustaining modern terrorist activities in the west and central African regional blocs, lyorchia Ayu (cited in Nwamu, 2014) has revealed the conspiratorial dimension of the insurgency in the northeast of the country. According to him, 'The oil wealth beneath the Chad Basin is fanning the embers of insurgency in the country because prominent businessmen and politicians in both Nigeria and Chad, in association with French companies, have invested heavily in oil exploration and exploitation'. He continues in the following manner, they are thus the 'principal financiers of, and arms suppliers to, Boko Haram. The group's destabilization of the north-eastern part of Nigeria benefits these investors because it delays exploration and production on the Nigerian side of Lake Chad. The Lake Chad Basin is estimated to have a reserve of 2.32 billion barrels of oil, and 14.65 trillion cubic feet of natural gas. The oil and gas flows underground across the countries sharing the Lake Chad Basin: Nigeria, Chad, Niger and Cameroun. Using 3D drilling, Chad is not only tapping oil within its territory but also from Nigeria, to push up its production levels'. It is not surprising therefore that Boko Haram anarchists currently consists Nigerians and a large hordes of Chadians; from the 'Chadian provinces of Lac and Hadjer Lamis - provinces that share a long border with north-eastern Nigeria around the Lake Chad region and provide Boko Haram with trained Chadian fighters' (Nwamu, 2014).

Back to the religious motivation of the Boko Haram, the earliest name they were identified with and the objective of the organization as made public by the membership of the upper echelon of the movement were said to be religious. 
They started their clandestine activities under an umbrella name which was commonly known as the Taliban. At a point, the name transmuted into what was generally referred to as the Ahlus sunna wal'jama'ah Hijra. Translated, it means 'the congregation of Followers of the prophet involved in the call to Islam and religious struggle'. In the search for the best name that should clearly depict the intentions and the purpose of the movement, they proceeded to still change their name. This time, they became the Jama'atu Ahlus Sunna Lidda Awati Wal Jihad which literarily means 'People Committed to the Prophet for Propagation and Jihad' (Alozieuwa, 2014: 144). Specifically, Imam Abubakar Muhammadu Abubakar bin Muhammed, also known as Abu Shekau had earlier giving the false impression that they were an Islamic movement. In an incendiary message he gave at the beginning of the insurgency, he is on record as having declared that 'our war is with the government that is fighting Islam; with the Christian Association of Nigeria (CAN) that are killing Muslims....and those who help them in fighting us even if they are Muslims. Anyone who is instrumental to the arrest of our members is assured that their own is coming' (Amnesty International, 2012: 10). Thus, everyone, irrespective of categorization is a victim of the Boko Haram; the soldier, police and other allied institutions within the security sector, the civil population including the clergy of the Christian and Muslim orientation, women, children and whoever is an unfortunate target of the sect.

With each 'victory' recorded by the Boko Haram, the organization grows bolder and brazen to the extent to dare the symbol of the nations' might as represented by the military institution and other security apparatuses like the State Security Services, the National Intelligence Agency (NIA), and the Defence Intelligence Agency (DIA). With regards its current mode of Operation, the Boko Haram or people claiming to be Boko Haram often issue outright threats to their potential victim(s) without any fear of the law Enforcement Agencies (LEAs). Some of these threats are dispatched through private correspondences-letters and telephone calls. Others are made through video mediums then posted on youTube (Amnesty International, 2012: 10). To the utmost surprise of observers of the trends and dynamics, and activities of the sect, once they issue such threats, they carry them out at almost exactly the time they say they will strike.

\section{Poverty in the Plague}

While many factors have been induced as an emergence to Boko Haram such as the fundamentalist question, however, new approaches have emerged to the causes Boko Haram based on anger and motivation into the recruitment ranks of the Boko Haram terrorist network. It is becoming clearly evident that the immediate and remote causes of the insurrection is beyond the fundamentalist question, another relevant theses is the poverty and the toxic messages propagated by religious extremist hiding under the garb of religion to stir and generate anger and bitterness towards the 'other'-the constructed enemy. This way, adherents are easily mobilized to perpetrate extremely heinous acts bordering on wickedness and evil (Mbillah, 2012). On the role of poverty, many have submitted that it has played a major role in motivating the youths in the traditional home of the Boko Haram -Northern Nigeria--into joining its ranks (Alozieuwa, 2013). It has been submitted that 'There has been general discontent in Nigeria from an army of unhappy, despondent, impoverished, or aggrieved citizens, some of whom are clearly and increasingly choosing a terrorist path' (Maiangwa and Okeke et. al, 2011).

On this issue, the well publicized Institute for Peace and Conflict Resolution's Strategic Conflict assessment of Nigeria (SCA) has rightly described Nigeria's North East's geo political zone as the most disadvantaged part in the commonwealth comprising the federation; the SCA has cited low life expectancy, endemic poverty and high illiteracy rates as some fundamental socio economic indicators that support this negative socioeconomic profile (IPCR, 2008: 81). The geography and demography of the region constitutes significant variables for consideration with regards to growth and sustainable human development. Geographically located near three international borders of the Niger Republic, Cameroun and Chad, and ecologically located in the Sahel with its attendant climatic challenges in the form(s) of desertification and the shrinkage of the most significant drainage system created by the Lake Chad. The region contends with dire scarcity of resources and other physical challenges. Iyorchia Ayu (cited in Nwamu, 2014), Nigeria's former President of the Senate has maintained that the drying up of Lake Chad, once the largest water body in Africa, is affecting the economic and social life of over 30 million people in the four countries around the lake. 'This has resulted in the migration of many farmers and herdsmen as well as engineered local conflicts between Cameroonian and Nigerian nationals; fishermen are fighting farmers and herdsmen to stop diverting water from the lake to their farms and livestock'. In addition,

The disappearance of Lake Chad and subsidiary rivers has also created a large population of unemployed and discontented youth who have become a reserve army easily available for recruitment by the insurgents. So far, Boko Haram has not attacked any territory in Chad but has a cluster of bases in Chad from where it launches its terrorist activities in Nigeria. President Idris Deby of Chad is said to have cordial relations with the insurgents (Nwamu, 2014). 
In addition, it is imperative to state that to be sure, decades of military dictatorships and civilian leadership that is reminiscent of the military autocratic regimes have been mired in a comparable mire of massive corruption. None of the combination of past and present ruling elites has provided the necessary socio-economic and political goods, such as physical infrastructure, primary health care, rule of law, and security to citizens. These are things that will translate to good governance and consequently a stable and virile state. 'It is no wonder that despite its massive oil wealth, Nigeria remains a largely poor country, with more than 80 percent of its citizens living on less than two dollars a day' (Adebajo, 2008: 2). It is also true that corrupt military despots and their civilian allies in an unholy union have failed 'dismally to transform the nation's natural wealth into great economic opportunities for many of its impoverished citizens. For example, General Sani Abatcha was estimated to have amassed a fortune of approximately US\$6 billion in four and a half years of his rule, largely siphoned from the national treasury and oil revenue, while the citizens simmered in anger at their deepening poverty' (Maier 2000:3). But this dismal imagery of corruption and its implication on the 'manufacturing of poverty' that is easily the cause of the rebellion against Nigeria and the authority presiding over it is not peculiar to the Abacha junta. Other like-minded governments equally siphoned billions of dollars and made these their booty from the privileged positions in government offices they occupied.

The implication of this development is that because of the scarcity and lack suffered by the people, they have become disappointed by the effort of the federal and state authorities to ameliorate their sufferings. This has occasioned the appeal of the Boko Haram to the thousand of youths that are drawn into the ranks of this infamous and highly rebellious sect. Recently, the United States policy establishment, operating under the United States Institute for Peace (USIP) has suggested that according to a study it carried out called the START, the core factors responsible for the appeal the Boko Haram has on the Youths in the North of Nigeria, hence influencing them included unemployment and poverty, manipulation by extremist religious leaders and deficiency in the authentic instructions of Islam suffered by a large number of the youths under discussion (Harper, 2014: 4).

A new twist to the Boko Haram challenge borders on the gradually evolving dynamic of girl-child suicide bombers that are contributing in the ravaging of the northern part of Nigeria. This tactic seemed to become popular after the Islamist group abducted over 200 girls from the rural community of Chibok; a small farming community in the southern fringes of Borno state, the state most affected by the insurrection since it started some seven years ago. The major reason terrorists use females in suicide missions is because women are less suspicious (Turkish Weekly, 2014). This occurrence has really send fear into the heart of the average Northern Nigeria citizen, resulting in the intimidation of the general population, which has imperiled human rights, people's privacy and family life. An equally precarious implication of the activities of the Boko Haram is the fact that it has successfully damaged community ties and family networks, and "consequently significantly impaired many people's quality of life"(Amnesty International, 2012: 11). The Amnesty international in the same 2012 has reported that the atmosphere of fear and general insecurity has forced many professionals like journalists, lawyers, medical practitioners, human rights activists to scale down or even completely abort their activities in these highly inflammable environment-the north East.

The seriousness and danger the group poses to the entire nation comprising its southern and northern sections is increasingly becoming ominous. Tatalo Alamu, a public policy analyst in Nigeria has expressed the fear that;

In a development that points at some international conspiracy, beyond the governments' tenuous grasps on reality, the murderous sect has the entire north within its rifle sight and it seems able to strike at will any target of choice even in Abuja, Nigeria's capital city. It is now beginning to probe the Southern underbelly of the nation in what promises to be an apocalyptic endgame for Nigeria. History has become a nightmare from which we are trying to wake up.

In the same precarious vein, even the entire swath of the west and Central African regions are easily located in the target sight of the sect. Just recently, in July 2014, the Boko Haram successfully invaded the northern Cameroonian town of Kolofata. Beyond wrecking immeasurable amount of damage to the area, including the killing of many of the inhabitants of the region, they also abducted high profiled officials of government including the wife of the deputy Prime Minister of Cameroun and the Lamido of kolofata (Guardian, 2014)

Following the rise in the state of insecurity to the state as a consequence of the activities of the Boko Haram, Nigeria has entered into agreement with France and four other of its immediate neighbors aimed at fashioning - out the best approach to be adopted in confronting the menace. The thrust of the agreement will be anchored essentially on the construction of a virile strategy for the coordination and exchange of intelligence; this is in addition to holding regular meetings of experts all with a view to conceiving the best approach to confronting the challenge (Owete, 2014). The countries that are signatories to the agreement are Benin Republic, Cameroun, Niger and the Republic of Chad. All these have agreed to ensure the effective "policing of common borders to avoid the infiltration of terrorists and other criminals as well as the repatriation of suspects in conformity with existing protocols (Owete, 2014)".

However, despite these seemingly proactive initiatives, all directed at the mitigation of the myriad of challenges to 
the state, the people and their previously functional institutions, cross - border crime and criminality including terrorism have persisted with dangerous implications characterizing their outcomes.

\section{Implications on Livelihoods}

Since its emergence in July 2009, the now renowned Boko Haram has perpetrated untold criminal actions against Nigeria and her citizenry. Within five years, this network of evil has killed thousands, maimed many more and destroyed properties worth billions of dollars. The group has claimed the responsibility for the serial "bombings and gun attacks across northern and Central Nigeria. The group has killed Muslim and Christian clerics, worshippers, politicians, journalists, lawyers as well as police and soldiers" (Amnesty International, 2012: 11). The group has equally claimed responsibility for doing even more as they are on record as having successfully hit at the strategic symbols of the Nigeria security establishments including the Police Force Headquarters and the Command and Staff College Jaji in Kaduna state. Apart from the brazen attacks on schools, churches, newspaper houses, prisons, thus freeing hundreds of prisoners, the Boko Haram had also claimed the responsibility for attacking the UN building and killing scores of its staff (Amnesty International, 2012: 10).

It was the highly devastating dimension the activities of the Boko Haram was taking especially the Nyanya bombing in April, 2014 that informed General Muhammadu Buhari's comments that run thus;

We must really stop and take notice of where evil is attempting to drive us to. We cannot allow these merchants of deaths to make us numb to the tragedy they manufacture. Those who were killed were not merely numbers on pages. They were human beings, made of flesh and blood, body and soul like the rest of us. They were someone's father or mother, brother or sister. They had parents; they were someone's child. They were husbands or wives, neighbors, friends and colleagues. They had dreams and hopes. They were loved and they loved others in return. Now life has been taken away from them, and those who cared for them must bear a grief nobody should be allowed to carry. These people committed no wrong. Their only crime was to be ordinary working people seeking to eke out a livelihood and fend for their families. For this they were killed.

Buhari proceeds in the same emotional vein,

They represent the backbone of the working people. Not many of them lived an easy life. Most worked hard and long for modest wages. They lifted themselves every morning to earn their daily bread they faced many social and economic challenges our society poses, yet they worked on not to destroy but to built and make this place a better place by bettering the lives of their family members and loved ones. These people lived and died the same way.

Still on the impairment of human livelihoods by the spate of insecurity as a result of the activities of the Boko Haram, it is important to mention at this juncture that the Boko Haram activies in the North East, especially in Borno which Borders three countries; Cameroun, Chad and Niger have anonymously greatly stressed and imperiled a thriving commercial chain that was instrumental in the integration and cooperation process that is the vision of the ECOWAS in a fast globalising economic and political order. The brute character of the strategy of the Boko Haram has caused the massive dispersal of lager scale agricultural and fishing communities from their original habitat to other settlements, whether inland or across the border. It is necessary to mention that these dispersed communities are responsible for the production of the wares needed as items of exchange in the international trade relations that characterized the activities of these regions and their contiguous international neighbors. In this respect, Wendy Sherman, the US under-secretary of state for political affairs has joined millions across the world in confirming that the Boko Haram conflict has "increased tensions between various ethnic communities, interrupted development activities, frightened off investors and generated concerns among Nigeria's northern neighbors (african.howzit.msn.com/article, 2014)".

\section{The Human Rights Question}

The concept of 'human rights' have assumed a new meaning since the beginning of the blitz of the Boko Haram in 1999. However, it has also taken a new twist since the declaration of the State of Emergency Policy on the North East zone of the country-the area most affected by the national peril of insecurity. With the increase to the challenge of insecurity as a result of killings, disfigurement, and the threat to the national sovereignty, the government of president Good Luck Jonathan acted proactively by pushing for the declaration of Martial law over the area as earlier mentioned, a decision accented to by the national Parliament. Specifically, in a nationwide broadcast, President Jonathan highlighted the reasons for his government's action to include the growing condition of insecurity in these troubled states. Thus, exercising his powers as enshrined in Section 305 Subsection 1 of the Nigerian Constitution, which empowers him as the Commander-in-Chief of the Nigerian Armed Forces and the chief security officer of the country to declare a state of 
emergency in any troubled area caused him to act accordingly. The President proceeded to maintain that the action is a crucial step to halting and eliminating the insurgency of the dreaded movement who have refused the offer of negotiations and reprieve extended to them by Nigeria's Federal authority.

It is thus this policy that has occasioned the deployment of massive numbers of troops and heavy military hardware to the three states affected by the policy-Adamawa, Borno and Yobe. These deployed military forces have accordingly deployed the strategy they are best accustomed to in tackling national emergencies like the Boko Haram debaclemaximum Force. In the process, many have been killed, maimed and displaced either as internally displaced people (IDPs) or as refugees traversing internationally boundaries.

\section{Recommendations and Conclusion}

Having exhaustibly discussed the issues, it is relevant to proffer recommendations that could contribute to the mitigation of the violence and the amelioration of the impacts of the same violent conflicts on the residents of this highly volatile region.

In this regards, no matter the direction of any discourse on the Boko Haram menace, it cannot be disputed that an important cause of the problem is to be easily tied to the increasing poverty of northern Nigeria especially its northeastern flank. It is the view of this paper that if the appeal the movement has on the ordinary rural folks and their urban counterparts is to be reduced, it is imperative that the core economic activities of the people, in this case agriculture, must as a matter of emergency be revamped.

The above position is important because in recent times, Nigeria and its government have grossly reducing the budgetary appropriation to this important sector. However, it must be recognized that agriculture is core to the alleviation of poverty, hunger and starvation; all conditions that culminate in human despair and misery, thus preparing the ground for motivating victims of these conditions to find 'solace' in the monstrous arms of the Boko Haram. In recent times, both Official Developments Assistance (ODA) and the private sector assistance have dramatically fallen. This informs the urgent need to recommend that these actors must be proactive in their partnership to funding agriculture. It is our view that apart from boosting the capacity of government to sustainably feed its beleaguered populations, it could also create millions of jobs for its teeming youths roaming the streets for nonexistent jobs; reduce poverty through improved income and earn more national income through the export of agricultural surpluses.

Over time it has become obvious that the pacifist approach to combating terrorism is increasingly becoming ineffectual because the insurgent movements have amassed large volumes of arm catches and their capacities greatly enhanced to consistently engage the national militaries of states. It is therefore imperative that the military response to the insurgency should urgently be re-examined. While it is not the conventional norm in traditional counter terrorism practices to engage with terrorist groups, it may be worthwhile to begin to explore the diplomatic/dialogue option due to the highly mutating nature of global terrorist networks. On this note, the paper suggests dialog option. Dialogue has the benefit of granting adherents of divergent orientations the opportunity to engage in discourses in previously unimagined ways. It breaks the wall of suspicion and distrusts and bridges the murky waters of hate and isolation that is the order in any conservative setting. Dialogue has proven that differences cannot stand in the way of men and women committed to the ideals of peace whose passion is skewed towards growth and sustainable human development. It is necessary to establish that while dialogue might not completely resolve contentious questions, it gives room for parties to conflicts to articulate their cases. It gives opportunity for aggrieved peoples to present their grievances in a civilized manner under an organized environment thus venting their angst, a major step in conflict resolution. This approach is recommended to the government and the Boko Haram as they agree to a diplomatic resolution of this heinous and evil motivated violent conflict.

Finally without sounding contradictory, the paper also wishes to observe that sometimes, the only guarantee of the absolute solution to a terrorist menace is through the total crushing of the terrorist. It is a universal truth that terrorists are a relentless foe that will settle for nothing less than total victory for their grotesquely conceived evil ideology. The only thing that can stop it, in this case the Boko Haram is total defeat. That is why it is important that Nigeria gets its military strategy right. This recommendation is apt because several reliable sources have confirmed that the Boko Haram has an advanced and sophisticated military arsenal that can sustainably engage the military in battle for long. It is therefore recommended that the Nigerian armed forces and the civilian authority overseeing its operations consider the urgency for advancing its amour and antiquated arsenal. When this happens, every resource must be deployed to the theatre of engagement for the assurances of a quick and decisive victory. This could be achieved only through a sound intelligence sharing mechanism between the military and other security agencies and these security agencies/military and the civil population in society. 
In conclusion, the paper has attempted to achieve a very important objective; that is to confirm that the Boko Haram is without doubt a terrorist organization by virtue of its modus operandi and international instruments and conventions defining the concept. We have also established the existing relationship between the lawlessness of the Boko Haram and the proliferation of illicit small arms and light weapons across the West Coast of the African Continent. This has eventuated in the massive blitzes that the Nigerian state and its people are subjected to. In fact some states of the north east-like Borno, Yobe and Adamawa--have been 'severed off' the country with the Boko Haram declaring parts of these states as Islamic Caliphate. And since this is the case, then the Nigerian government and its revered military and security establishments must consider it important to unreservedly deploy every resource at its disposal to counter this threat to human lives and their precious belongings. This is crucial because the menace is already a major setback to foreign direct investments (FDI), the movement towards sub-regional integration through the free movements of goods and services and the entire process of globalization that is undoubtedly beneficial to all, especially the poor regions of the world in this Century and beyond.

\section{References}

Aliyu, Abdullahi (1998). Nigerian Economic Breakthrough, Abuja: The Family Economic Advancement Programme (FEAP)

Alobi, E.L. (2014). "Review Of Nigeria's Efforts At Combating Small Arms And Light Weapons (SALW) Proliferation: The NATCOM Experience" Presented at the National Consultative Forum on the Proliferation of Small Arms And Light Weapons (SALW) Held At The Auditorium ECOWAS Commission, Yakubu Gowon Crescent Asokoro, Abuja On 2-4 June.

Aloziuwa, Simon (2014). The Role of Women in the Boko Haram Movement and Insurgency. In the Journal of Review of Nigerian Political Economy (RONPE). Volume 2, No. 1 \& 2-Dcember January-December.

Berman, Eric (2014). 'Trends and Dynamics of Illicit Arms Proliferation in Nigeria': A Small Arms Survey's Perspective. A Presentation at the Consultative Forum on the Proliferation of Small Arms And Light Weapons (SALW) Held At The auditorium of the ECOWAS Commission, Yakubu Gowon Crescent Asokoro, Abuja On 2-4 June.

Bernstein, Sarah (2012) "Is 'Interreligious' Synonymous with 'Interfaith'? The Roles of Dialogue in Peacebuilding. In Darweish, Marwan and Cariol Rank (Eds). Peacebuilding and Reconcilliation: Contemporary themes and Challenges, London: Pluto Press.

Boko Haram hinders Nigeria's development; African. Howzit.msn.com/Article. Accessed on the 1st day of August, 2014.

Born, Hans (2003). Parliamentary Oversight of the Security Sector, Geneva: Geneva Centre for the Democratic Control of the Armed Forces.

Bull, Hedley (1977). The Anarchical Society, London: Macmillan Educational Limited.

Cilliers, Jakkie. \& Hughes, Barry et al (2011). African Futures 2050: The Next Forty Years, Pretoria: Instutute for Security Studies.

Fukuyama, Francis (1992). The End of History and the Last Man, London: Penguin Group.

Gurr, Ted Robert 1970. Why Men Rebel. Princeton: Princeton University Press.

Lohmann, A.(2011), Who Owns the Sahara? Old Conflicts, New Menaces: Mali and the Central Sahara Between the Tuareg, AlQaida and Organised Crime. Abuja: FRIEDRICH EBERT STIFTUNG

Hobbes, Thomas (1946). Leviathan. Lodon: Blackwell.

Mamdami, Mahmud. Good Muslim Bad Muslim: A Political Perspective on Culture and Terrorism. American Anthropologist. Vol 104. No 3. Sept. 2002.

Harper, L (2014) 'What's Behind Latest Nigeria Attacks by Boko Haram?' http://www.Usip.org/olivebranch/what-s-behind-latest-nigeriaattacks-boko-aram.Accessed $12^{\text {th }}$ March, 2014.

Idris, Abdullahi (2014). $3^{\text {rd }}$. Boko Haram Territory Larger than 3 States: over 20, $000 \mathrm{sq} \mathrm{Km}$ under Occupation. The Daily Trust, November 3rd.

Laderach, John Paul (1997). Building Peace: Sustainable Reconciliation in Divided Societies. Washington D.C.: United States Institute of Peace Press.

Mbillah, Johnson (2012). Africa Christian and Muslim Religious Leaders Conference on Peace and Development: Addis Ababa Report. Nairobi: Acken Media Services.

Nagarta Radio: 'A Documentary on the Profile of International Refugee and Internally Displaced People' in June, 2014.

Nigeria; Trapped in the Cycle of Violence. A Publication of the Amnesty International. London: Peter Benson House, 2012.

Nilufer Karacasulu (2006). Security and Globalization in the Context of International Terrorism: in the Review of International Law and Politics, Vol. 2, No. 5.

Reuter, C. (2002). My life is a weapon; modern history of suicide bombings, Princeton: Princeton University Press.

Oche, Ogaba (2009).' ECOWAS and the Challenge of Trans-Border Crimes'. In Ogwu, Joy and Alli, Warisu (Eds). ECOWAS: Milestones in Regional Integration, Lagos: Nigerian Institute for International Affairs.

Ocholi, D. (2014). Nyanya Bomb Blast and the Fight against Terrorism in Nigeria. In the Verbatim Publication of May $12^{\text {th }}$

Okafor, Obiora Chinedu "Newness, Imperialism, and International Legal Reform in Our Time: A TWAIL Perspective" in Osgoode Hall Law Journal [Vol. 43, No. 1 \& 2, 2005].

Owete, Festus (2014) Combating the Boko Haram Onslaught through Proactive Measures. www.premiumtimesng.com/authors/festus. acessed 30th, October, 2014.

Paige, G.D., (2009). Nonkilling Global Political Science, USA: Centre for Global Nonkilling, Xlibris Corporation. 
Pelaia, Ariela (2012). 'What Was the Great Revolt and the Destruction of the Second Temple. Accessed@judaism.about.com/od/ jewishhistory/a/greatrevolt.htm. August, 2014.

Rousseau, Jean Jacques (1927). A project of Perpetual Peace. London: Danderson.

Turkish Weekly (2014). "Female terrorism in Nigeria on the rise as girls, women bomb civilians" 31st July.

Salkida, Ahmad (2009). Sect Leader Vows Revenge. Daily Trust, 27 July.

Sanda, Julie G. (2004). Democratic Governance and Regional Security in West Africa. Lagos: Frankard Publishers.

Strategic Conflict Assessment of Nigeria (2008). Consolidated and Zonal Reports, Abuja: Institute for Peace and Conflict Resolution.

The guardian 'Cameroon deputy prime minister's wife kidnapped by Boko Haram' www.theguardian.com/.../cameroon-boko-haramkindap-kolofata

Yusha'u Ibrahim (2014). 2,000 Fled to Niger Republic. The Daily Trust, November $4^{\text {th }}$.

\section{Online Publications}

A.D. 70 Titus Destroys Jerusalem. http://www.christianitytoday.com/ch/1990/ issue28/2808.html. Accessed on 4th August, 2014.

Nwamu, Aniebo (2014) The mystery behind the Boko Haram group, their incentives and the reason behind their sporadic attacks. In the Leadership Newspaper. Available at http://www.nigerianbulletin.com/threads/boko-haram-mystery-solved.99398/ (Accessed on $15 / 11 / 2014)$ 